\title{
Nisin activity against methicillin-resistant and methicillin-sensitive Staphylococcus aureus and risk of resistance acquisition
}

\author{
Atividade da nisina contra Staphylococcus aureus resistente e sensível à meticilina e risco de \\ aquisição de resistência \\ Actividad de nisina contra Staphylococcus aureus resistente y sensible a meticilina y riesgo de \\ adquisición de resistência
}

Received: 05/17/2021 | Reviewed: 05/24/2021 | Accept: 05/31/2021 | Published: 06/13/2021

\author{
César Matos Ribeiro da Silva \\ ORCID: https://orcid.org/0000-0002-9826-3241 \\ Universidade Federal de Sergipe, Brazil \\ E-mail: cesarribeirinho@gmail.com \\ Waleska da Silva Albuquerque \\ ORCID: https://orcid.org/0000-0001-6414-4298 \\ Universidade Federal de Sergipe, Brazil \\ E-mail: waleska_silva_albuquerque@ hotmail.com \\ Jucyara Natállia Araujo de Oliveira \\ ORCID: https://orcid.org/0000-0001-6260-166X \\ Universidade Federal de Sergipe, Brazil \\ E-mail: jucyara92@gmail.com \\ Maria Regina Pires Carneiro \\ ORCID: https://orcid.org/0000-0002-6107-4965 \\ Universidade Federal de Sergipe, Brazil \\ E-mail:profregina@hotmail.com \\ Sona Jain \\ ORCID: https://orcid.org/0000-0002-5999-931X \\ Universidade Tiradentes, Brazil \\ E-mail: sonajain24@yahoo.com \\ Silvio Santana Dolabella \\ ORCID: https://orcid.org/0000-0001-5576-3214 \\ Universidade Federal de Sergipe, Brazil \\ E-mail: dolabellaufs@gmail.com \\ Ana Andréa Teixeira Barbosa \\ ORCID: https://orcid.org/0000-0003-1271-7546 \\ Universidade Federal de Sergipe, Brazil \\ E-mail: ana.barbosaufs@yahoo.com.br
}

\begin{abstract}
The objective of this study was to analyze the antimicrobial effect of nisin against MRSA (Methicillin-Resistant Staphylococcus aureus) and MSSA (Methicillin-Sensitive Staphylococcus aureus), and at the same time examine the possibility of the bacteria to develope nisin resistance. The antimicrobial susceptibility of the strains was tested using the agar diffusion and/or microdilution methods. To select nisin-resistant strains, bacteria were grown consecutively at sublethal concentrations of the bacteriocin. Nisin showed bactericidal activity against most of the tested strains. MRSA required higher doses of bacteriocin compared to MSSA both for inhibition and cell death. However, transfers in the presence of nisin could completely eliminate nisin activity with an increase in minimal inhibitory concentration value of up to 250 times. Nisin-resistance could be maintained in MRSA and MSSA even in the absence of the bacteriocin. Nisin resistance affected antibiotic susceptibility of both MRSA and MSSA to mainly Cefoxitin, Oxacillin, and Erythromycin. These results indicate that nisin-resistance is a complex trait among MSSA and MRSA and must be elucidated before the therapeutic recommendation of nisin to treat infections caused by these bacterial species.
\end{abstract}

Keywords: Antibiotic resistance; Antimicrobial activity; Bacteriocin; Staphylococcus aureus.

\section{Resumo}

O objetivo deste estudo foi analisar o efeito antimicrobiano da nisina contra MRSA (Staphylococcus aureus resistente à meticilina) e MSSA (Staphylococcus aureus sensível à meticilina) e, ao mesmo tempo, examinar a possibilidade da bactéria desenvolver resistência à nisina. A susceptibilidade antimicrobiana das cepas foi testada pelos métodos de difusão em ágar e /ou microdiluição. Para selecionar cepas resistentes à nisina, as bactérias foram cultivadas 
consecutivamente em concentrações subletais da bacteriocina. A nisina apresentou atividade bactericida contra a maioria das cepas testadas. MRSA exigiu doses mais altas de bacteriocina em comparação com MSSA, tanto para inibição quanto para morte celular. No entanto, as transferências na presença de nisina podem eliminar completamente a atividade da nisina com um aumento no valor da concentração mínima inibitória de até 250 vezes. A resistência à nisina pode ser mantida em MRSA e MSSA mesmo na ausência da bacteriocina. A resistência à nisina afetou a suscetibilidade das linhagens principalmente aos antibióticos cefoxitina, oxacilina e eritromicina. Esses resultados indicam que a resistência à nisina é uma característica complexa entre MSSA e MRSA e deve ser elucidada antes da recomendação terapêutica da bacteriocina para o tratamento de infecções causadas por esse microrganismo.

Palavras-chave: Resistência a antibióticos; Atividade antimicrobiana; Bacteriocina; Staphylococcus aureus.

\section{Resumen}

El objetivo de este estudio fue analizar el efecto antimicrobiano de la nisina contra MRSA y MSSA (Staphylococcus aureus resistente a meticilina y sensible a meticilina), y al mismo tiempo examinar la posibilidad de que la bacteria desarrolle resistencia a la nisina. La susceptibilidad antimicrobiana de las cepas se evaluó mediante los métodos de difusión en agar y / o microdilución. Para seleccionar cepas resistentes a la nisina, se cultivaron bacterias consecutivamente a concentraciones subletales de la bacteriocina. La nisina mostró actividad bactericida contra la mayoría de las cepas probadas. MRSA requirió dosis más altas de bacteriocina en comparación con MSSA tanto para la inhibición como para la muerte celular. Sin embargo, las transferencias en presencia de nisina podrían eliminar completamente la actividad de la nisina con un aumento en el valor de MIC de hasta 250 veces. La resistencia a la nisina podría mantenerse en MRSA y MSSA incluso en ausencia de la bacteriocina. La resistencia a la nisina afectó la susceptibilidad antibiótica de MRSA y MSSA principalmente a cefoxitina, oxacilina y eritromicina. Estos resultados indican que la resistencia a la nisina es un rasgo complejo entre MSSA y MRSA y debe aclararse antes de la recomendación terapéutica de la nisina para tratar infecciones causadas por estas especies bacterianas.

Palabras clave: Resistencia a antibióticos; Actividad antimicrobiana; Bacteriocina; Staphylococcus aureus.

\section{Introduction}

Antibiotic resistance among bacteria is one of the greatest challenges experienced by the health sector all over the world (Bauer \& Sampathkumar, 2017; Saha et al., 2017; Vivas et al., 2019). This phenomenon implies a diminishing existence of effective antimicrobial agents to treat infections caused by these bacteria (Magiorakos et al., 2012; Lin et al., 2017). Among antibiotic-resistant bacteria, methicillin-resistant Staphylococcus aureus (MRSA) is spreading worldwide in both hospital (HAMRSA) and community (CA-MRSA) settings, including livestock animals (LA-MRSA) (Castro et al., 2017; Lakhundi \& Zhang, 2018; Lozano et al., 2020; Togneri et al., 2017). Infections caused by MRSA constitute one of three major infectious diseases, threatening human health (Center for Disease Control and Prevention, 2015; Lozano et al., 2020; Togneri et al., 2017). Recently, MRSA has also been a problem as a co-infection in patients with COVID-19 (Punjabi et al., 2020; Sharifipour et al., 2020).

In the past, infections caused by $S$. aureus were easily treated by penicillin. However, $S$. aureus acquired a plasmidencoded beta-lactamase that conferred resistance to penicillin shortly after its introduction for clinical use. In 1959, methicillin, a semisynthetic beta-lactamase-resistant antibiotic, was developed and introduced to combat penicillin-resistant strains. Unfortunately, as evidenced by current scenarios, methicillin-resistant strains emerged quickly (Hiramatsu et al., 1990; Lozano et al., 2020). One of the major concerns today is the emergence of vancomycin and daptomycin-resistant S. aureus (Cafiso et al., 2020; Kang et al., 2015; Pader \& Edwards, 2017).

In this context, the development of alternative methods for the control of infections caused by $S$. aureus is urgent. Bacteriocins have been proposed as promising alternative methods to control MRSA (Hanchi et al., 2017; Kranjec et al., 2020; Okuda et al., 2013). Nisin, a lantibiotic bacteriocin produced by Lactococcus lactis, has shown application in the food industry as a natural preservative and is approved for use in more than 50 countries (Center for Disease Control and Prevention, 2015; Cleveland et al., 2001; Field et al., 2015; Gedarawatte et al., 2021). The clinical use of this bacteriocin in human medicine is not approved, but several studies have shown its potential in this field, including the control of antibiotic-resistant pathogens (Hayes et al., 2019; Okuda et al., 2013; Shin et al., 2016). 
Considering that $S$. aureus has developed resistance to all the antibiotics currently available for its control, before the application of new antimicrobials, it is important to examine the possible effects of this antimicrobial on the selection of resistant strains. Bacteriocin-resistance among MRSA has not been fully investigated. Therefore, the objective of this study was to investigate the effect of nisin against MRSA and MSSA (methicillin-sensitive Staphylococcus aureus) and the selection of nisin-resistant strains among these bacteria.

\section{Methodology}

\subsection{Microorganisms and Growth Conditions}

The $S$. aureus strains $(\mathrm{n}=36)$ included in this study belong to the culture collection of the Laboratory of Bacteriology of the Department of Morphology, Federal University of Sergipe, Brazil. The strains were isolated from oro/nasopharyngeal secretions of health professionals working at a Municipal Hospital in Aracaju, Sergipe, Brazil. The human isolates were phenotypically identified as part of a larger MRSA study for which ethical approval was obtained from the Research Ethics Committee of the Federal University of Sergipe, under registration CAAE no 0044.0.107.000-11.

The cultures were grown at $35^{\circ} \mathrm{C}$ in Sal Manitol Agar (Acumedia, Lansing/EUA) and subjected to Gram staining and microscopic analysis to confirm the purity. For the remaining experiments, MRSA and MSSA were cultured in BHI (Brain Heart Infusion, Himedia, Mumbai/India) or MH medium (Mueller Hinton, Himedia, Nashik/India) at $35^{\circ} \mathrm{C}$. The control strains used in this study were: S. aureus ATCC33591 (MRSA/mecA and lukPV positive/mecC negative), S. aureus ATCC25923 (MSSA/mecA, mecC and lukPV negative), and S. aureus ATCC1874a (MRSA/mecC positive/lukPV and mecA negative).

\subsection{Genetic Characterization of MRSA and MSSA strains}

Considering that the strains used in this study were previously identified by phenotypic characteristics, genetic analyses using the primers described in Table 1 were performed to confirm the species identification and the resistance phenotypes.

Table 1. Primers used for genetic characterization of MRSA and MSSA strains.

\begin{tabular}{llll}
\hline Gene & Primer & Sequence 5'-3' & Reference \\
\hline nисA & NUC1 & GCGATTGATGGTGATACGGTT & Zhang et al., 2004 \\
& NUC2 & AGCCAAGCCTTGACGAACTAAAGC & \\
\hline \multirow{2}{*}{ mecA } & MecA-F & TCCAGATTACAACTTCACCAGG & Oliveira \& De Lencastre, \\
& MecA-R & CCACTTCATATCTTGTAACG & 2002 \\
\hline mecC & MecC-F & GAAAAAAAGGCTTAGAACGCCTC & García-Álvarez et al., 2011 \\
& MecC-R & AAGATCTTTTCCGTTTTCAGC & \\
\hline \multirow{2}{*}{$l u k P V$} & LukPV-F & ATCCGAGAGACTATTTTGTGC & Ribeiro et al., 2005 \\
& LukPV-R & CATCAACCTTTTTCTCACTTAC & \\
\hline
\end{tabular}

Source: Authors.

Total DNA was isolated from S. aureus strains using the Wizard Genomic DNA purification Kit (Promega, Madison, WI, USA) according to the manufacturer's instructions. PCR reactions were performed in a Veriti ${ }^{\circledR}$ Thermal Cycler (Applied Biosystems, Foster City, CA, USA) and PCR cycles proceeded as follows: initial step at $94^{\circ} \mathrm{C}$ for 5 min, 40 cycles at $94^{\circ} \mathrm{C}$ for $1 \mathrm{~min}, 55^{\circ} \mathrm{C}$ for $30 \mathrm{sec}, 72^{\circ} \mathrm{C}$ for $1 \mathrm{~min}$, and a final extension at $72^{\circ} \mathrm{C}$ for $5 \mathrm{~min}$. Negative controls (sterile water) were used in all reactions. 


\subsection{Antimicrobial Activity of Nisin Against MRSA and MSSA strains}

Nisin solution (Chrisin C; CHL Hansen, $1000 \mathrm{UI} / \mathrm{mg}$ ) was prepared at a concentration of 1000 IU-International units of nisin $/ \mathrm{mg}$ in $\mathrm{NaCl}$ solution $(0.85 \%, \mathrm{pH} 2.0)$. The antimicrobial spectrum of nisin against $S$. aureus strains was initially tested with the agar diffusion method described by Hoover and Harlander (1993). Approximately $106 \mathrm{CFU} / \mathrm{mL}$ of the S. aureus strains standardized by the McFarland scale were inoculated using the spread plate method on BHI agar $(15 \mathrm{~mL})$ in petri dishes (90x15 mm). Holes of $5 \mathrm{~mm}$ diameter were made into the agar and filled with an aliquot of $25 \mu \mathrm{l}$ of nisin (1000 IU/ml). The plates were incubated for approximately 16 hours at $4^{\circ} \mathrm{C}$ for diffusion of the bacteriocin and subsequently incubated at $35^{\circ} \mathrm{C}$. After $24 \mathrm{~h}$ of incubation the presence of inhibition zones was observed.

The strains sensitive to nisin in the diffusion method were analyzed for Minimal Inhibitory Concentration (MIC) and Minimal Bactericidal Concentration (MBC) using the micro dilution method as described by the Clinical and Laboratory Standards Institute (CLSI, 2019). MIC was defined as the lowest concentration required to completely prevent bacterial growth for $24 \mathrm{~h}$ and $\mathrm{MBC}$ as the lowest concentration that inactivated all the cells, which was confirmed by the growth inhibition in solid medium.

\subsection{Selection of Nisin-Resistant Strains}

To select nisin-resistant strains of $S$. aureus, cultures were transferred every 12 hours to BHI medium containing sublethal doses of the bacteriocin, that is, $50 \%$ of the MIC value. Bacteriocin activity against the strains was monitored after each transfer using the agar diffusion method, where nisin was serially diluted (2-fold) in $\mathrm{NaCl}$ solution (100 mM, pH 2.0) and tested for antimicrobial activity. One arbitrary unit (AU) was defined as the reciprocal of the highest dilution that showed an inhibition zone. After the last transfer, when no inhibition zone was observed, MIC determinations were redone as described in the previous section. To verify whether bacteriocin resistance is a stable phenotype, nisin-resistant strains were transferred to BHI medium without bacteriocin and MIC was determined at the end of the experiment. These analyses were carried out with MRSA strains ( $n=5)$ and MSSA strains $(n=6)$ with different degrees of sensitivity to nisin, considering the MIC value of the strains.

\subsection{Antibiotic Disk Diffusion Susceptibility Test}

Patterns of resistance/susceptibility to antibiotics of wild type and bacteriocin resistant variants were studied using the disc diffusion method as recommended by CLSI ((Clinical and Laboratory Standarts Institute, n.d.). Antibiotic discs containing erythromycin (ERI/10 $\mu \mathrm{g}$ ), gentamicin (GEN/10 $\mu \mathrm{g}$ ), cefoxitin (CFO/30 $\mu \mathrm{g}$ ), clindamycin (CLI/02 $\mu \mathrm{g}$ ), oxacillin (OXA/30 $\mu \mathrm{g}$ ), and ciprofloxacin $(\mathrm{CIP} / 05 \mu \mathrm{g})$ were purchased from HiMedia. The susceptibility test was performed with wild type strains (S1), nisin-resistant strains (S2- strains that were consecutively transferred to BHI medium containing sub lethal doses of nisin) and with nisin-resistant strains consecutively transferred to BHI broth without nisin (S3).

\subsection{Statistics}

All experimental procedures were carried out in triplicate and repeated at least twice. The results obtained were submitted to analysis of variance at $5 \%$ of probability, and means were compared with Tukey's test using the SAS statistical software (Statistical Analysis Systems, 2004). In the tables, data represent arithmetic mean values and, when applicable, the standard deviation of the mean. 


\section{Results}

\subsection{Genetic Characterization of MRSA and MSSA Strains}

All the tested strains were positive for the presence of the $n u c \mathrm{~A}$ gene and negative to the $m e c \mathrm{C}$ gene. The phenotypically identified MRSA strains were also positive for the presence of the mecA and lukPV genes, confirming the methicillinresistance phenotype and that these strains are probably related to community settings. As expected, no methicillin resistance or $l u k \mathrm{PV}$ genes were detected in the MSSA strains (results not shown).

\subsection{Antimicrobial Activity of Nisin Against MRSA and MSSA Strains}

Among the MSSA strains $(n=30)$ analyzed in this study, approximately $83 \%$ were sensitive to nisin forming inhibition zones. The MIC values of nisin-sensitive MSSA strains ranged from 97.7 to $1250 \mathrm{IU} / \mathrm{mL}$, but most strains had MIC values equal to $390.6 \mathrm{IU} / \mathrm{mL}$ (Table 2). Among the sensitive strains, $40 \%$ showed MIC value equal to MBC value, indicating that the action of nisin against these strains is bactericidal. However, for $48 \%$ of the MSSA strains, MBC reached a superior value of 50000 $\mathrm{IU} / \mathrm{mL}$, probably because in these strains nisin exerts only a bacteriostatic effect. For 3 strains (MSSA21, 27, and 29) the effect of nisin was found to depend on the concentration, showing bacteriostatic effect at low concentrations and bactericidal effect at high concentrations (Table 2). Among the MRSA strains ( $n=6$ ), the inhibition zone was not observed only for one strain. The MIC values ranged from $468.75 \mathrm{IU} / \mathrm{mL}$ to $1250 \mathrm{IU} / \mathrm{mL}$ and $\mathrm{MBC}$ values ranged from $625 \mathrm{IU} / \mathrm{mL}$ to values higher than 50000 $\mathrm{IU} / \mathrm{mL}$. MBC was always higher than MIC, indicating that for MRSA strains, nisin has bacteriostatic effect at low concentrations and is bactericidal at high concentrations. However, similar to MSSA strains, in the case of MBC values higher than $50000 \mathrm{IU} / \mathrm{mL}$, nisin probably is only bacteriostatic (Table 2).

\subsection{Selection of Nisin-resistant MRSA and MSSA}

When MSSA were cultured in the presence of sublethal doses of nisin, a complete loss of bacteriocin activity (nisin-resistant MSSA) was observed after 30 transfers (analyzed by the diffusion method, results not shown). In this case, MIC values (MIC2) of all the strains increased up to 250 times, indicating nisin resistance (Table 3). Even after consecutive cultivation of these strains in the absence of bacteriocin, MIC values remained high (MIC3, Table 3). For MRSA, 25 transfers were sufficient to completely exclude nisin activity (analyzed by the diffusion method, results not shown), and the MIC values also increased up to 250 times (MIC2, Table 3). This increase was stable even when the strains were cultured consecutively 20 times in the absence of nisin (MIC3, Table 3). The results obtained for MSSA and MRSA were also obtained for the standard reference strains S. aureus ATCC25923 (MSSA/mecA, mecC and lukPV negative) and S. aureus ATCC33591 (MRSA/mecA and lukPV positive/mecC negative). 
Table 2. Nisin activity against methicillin-sensitive (MSSA) and methicillin-resistant (MRSA) Staphylococcus aureus. Presence (+) or absence (-) of inhibition zone and MIC and MBC values are shown. When applicable, the standard deviation of the mean is also indicated.

\begin{tabular}{|c|c|c|c|}
\hline Strain & Inhibition zone & $\mathrm{MIC}(\mathrm{IU} / \mathrm{mL})$ & $\mathrm{MBC}(\mathrm{IU} / \mathrm{mL})$ \\
\hline MSSA01 & - & ND & ND \\
\hline MSSA02 & + & $97.70 \pm .0 .80 *$ & $97.70 \pm .0 .80$ \\
\hline MSSA03 & + & $781.10 \pm 1.10$ & $>25000$ \\
\hline MSSA04 & + & $390.60 \pm 0.50$ & $390.60 \pm 0.50$ \\
\hline MSSA05 & + & $195.30 \pm 1.81$ & $195.30 \pm 1.81$ \\
\hline MSSA06 & + & $195.30 \pm 1.81$ & $195.30 \pm 1.81$ \\
\hline MSSA07 & + & $234.40 \pm 0.66$ & $234.40 \pm 0.66$ \\
\hline MSSA08 & + & $781.20 \pm 0.70$ & $>50000$ \\
\hline MSSA09 & + & $390.60 \pm 0.50$ & $>50000$ \\
\hline MSSA10 & + & $390.60 \pm 0.50$ & $>50000$ \\
\hline MSSA11 & + & 312.50 & $>50000$ \\
\hline MSSA12 & + & 1250 & 1250 \\
\hline MSSA13 & + & $390.60 \pm 0.50$ & $>50000$ \\
\hline MSSA14 & + & $292.90 \pm 1,40$ & $292.90 \pm 0,14^{*}$ \\
\hline MSSA15 & + & $390.60 \pm 0.50$ & $>50000$ \\
\hline MSSA16 & - & ND & ND \\
\hline MSSA17 & - & ND & ND \\
\hline MSSA18 & - & ND & ND \\
\hline MSSA19 & - & ND & ND \\
\hline MSSA20 & + & $195.30 \pm 1.81$ & $>50000$ \\
\hline MSSA21 & + & $195.30 \pm 1.81$ & $4688 \pm 0.81$ \\
\hline MSSA22 & - & ND & ND \\
\hline MSSA23 & + & $351,60 \pm 1,6$ & $>50000$ \\
\hline MSSA24 & + & 312.50 & $312.50 \pm 0.88$ \\
\hline MSSA25 & + & $234.30 \pm 0.66$ & $234.30 \pm 0.66$ \\
\hline MSSA26 & + & $390.60 \pm 0.50$ & $>50000$ \\
\hline MSSA27 & + & 156.20 & $195.30 \pm 1.81$ \\
\hline MSSA28 & + & $390.60 \pm 0.50$ & $>50000$ \\
\hline MSSA29 & + & $488.20 \pm 4,8$ & $878.90 \pm 0.66^{*}$ \\
\hline MSSA30 & + & $293.00 \pm 1,40$ & $293.0 \pm 1,40 *$ \\
\hline S. aureus ATCC $25923^{\bullet}$ & + & 1250 & $>50000$ \\
\hline MRSA02 & - & ND & ND \\
\hline MRSA03 & + & 1250 & $>5000$ \\
\hline MRSA04 & + & $468.75 \pm 0.97 *$ & $>5000$ \\
\hline MRSA05 & + & 625 & $>5000$ \\
\hline MRSA06 & + & 1250 & 2500 \\
\hline MRSA07 & + & $937.50 \pm 0.94$ & 2500 \\
\hline S. aureus ATCC $33591^{\star}$ & + & $468.75 \pm 0.97$ & 625 \\
\hline
\end{tabular}

$*$ Standard deviation ND $=$ Not Determined $\bullet$ MSSA reference strains ${ }^{\bullet}$ MRSA reference strain. Source: Authors. 
Table 3. Effect of nisin on the selection of resistant strains. The strains were transferred successively in the presence of sublethal dose of nisin and the MIC values were determinate (MIC2). After transferring in the absence of nisin, MIC values were measured again (MIC3). The initial MIC value of strains (MIC1) is also shown. When applicable, the standard deviation of the mean is indicated.

\begin{tabular}{lccc}
\hline Strain & MIC1 $(\mathrm{IU} / \mathrm{mL})$ & MIC2(IU/mL) & MIC3(IU/mL) \\
\hline MSSA02 & $97.70 \pm .0 .80^{*}$ & $>25000$ & $>25000$ \\
MSSA07 & $234.40 \pm 0.66$ & 15000 & $>25000$ \\
MSSA09 & $390.60 \pm 0.50$ & $>25000$ & $>25000$ \\
MSSA12 & 1250 & 10000 & $>25000$ \\
MSSA14 & $292.90 \pm 1,4$ & $>25000$ & $>25000$ \\
MSSA29 & $488.20 \pm 4,8$ & $>25000$ & $>25000$ \\
S. aureus ATCC25923• & 1250 & $>25000$ & $>25000$ \\
MRSA03 & 1250 & $>25000$ & $>25000$ \\
MRSA04 & $468.75 \pm 0.97 *$ & $>25000$ & $>25000$ \\
MRSA05 & 625 & $>25000$ & $>25000$ \\
MRSA06 & 1250 & $>25000$ & $>25000$ \\
MRSA07 & $937.5 \pm 0.94$ & $>25000$ & $>25000$ \\
S. aureus ATCC33591 & $468.75 \pm 0.97$ & $>25000$ & $>25000$ \\
\hline
\end{tabular}

- MSSA reference strains ${ }^{\bullet}$ MRSA reference strain.

Source: Authors.

\subsection{Antibiotic Disk Diffusion Susceptibility Test}

Three MSSA (07, 09 and 14) strains sensitive to CFO and OXA showed resistance to these antibiotics after growth in the presence of nisin(S2) and then without nisin (S3). The same observation was made for the standard reference strain (S. aureus ATCC25923) when tested against CFO. For CLI, GEN and CIP, no difference in sensibility was observed after transfer with and without bacteriocin. Only MSSA09 showed resistance to ERI (Table 4).

MRSA03 became CFO and OXA sensitive after being transferred in the presence of nisin (S2) and this phenotype continued even after being transferred in absence of nisin twenty times (S3) (Table 5). The MRSA04 became sensitive to these antibiotics after growth in the presence of sublethal dose of nisin, however, when the strain was grown in the absence of nisin, the CFO and OXA resistance phenotype was resumed. The same occurred when OXA was tested against all the other MRSA strains, including the standard reference strain S. aureus ATCC33591. For CLI, GEN, and CIP no altered sensibility was present among MRSA strains (Table 5). Unlike MRSA strains, the standard reference strain (S. aureus ATCC33591) was initially CLI resistant became CLI sensitive in the presence of nisin. Besides, all the MRSA tested, except for the standard reference strain (S. aureus ATCC33591), which was initially sensitive to ERI, became ERI-resistant after growth in the presence and later in the absence of nisin (Table 5). 
Table 4. Susceptibility to antibiotics in methicillin-sensitive Staphylococcus aureus (MSSA) wild type strains (S1), nisin-resistant strains (S2) and nisin-resistant strains consecutively transferred in BHI broth without nisin (S3).

\begin{tabular}{|c|c|c|c|c|c|c|c|}
\hline $\begin{array}{ll} & \text { Antibiotic } \\
\end{array}$ & & $\mathrm{CFO}$ & CLI & OXA & ERI & CIP & GEN \\
\hline \multicolumn{8}{|l|}{ Strain } \\
\hline \multirow[t]{3}{*}{ MSSA02 } & S1 & $\mathrm{S}$ & $\mathrm{S}$ & $\mathrm{S}$ & $\bar{S}$ & $\mathrm{~S}$ & I \\
\hline & S2 & $S$ & $S$ & S & S & $S$ & S \\
\hline & S3 & $\mathrm{S}$ & $S$ & $\mathrm{~S}$ & $S$ & $S$ & $S$ \\
\hline \multirow[t]{3}{*}{ MSSA07 } & S1 & $\bar{S}$ & $\bar{S}$ & $\bar{S}$ & I & $\bar{S}$ & $\bar{S}$ \\
\hline & S2 & S & S & S & S & S & S \\
\hline & S3 & $\mathrm{R}$ & $S$ & $\mathrm{~S}$ & $S$ & $S$ & $\mathrm{~S}$ \\
\hline \multirow[t]{3}{*}{ MSSA09 } & S1 & $\bar{S}$ & $\bar{S}$ & $\bar{S}$ & $\bar{S}$ & $\bar{S}$ & $\bar{S}$ \\
\hline & S2 & $S$ & S & S & S & $S$ & I \\
\hline & S3 & $\mathrm{R}$ & $\mathrm{I}$ & $\mathrm{R}$ & $\mathrm{R}$ & $\mathrm{S}$ & $\mathrm{S}$ \\
\hline \multirow[t]{3}{*}{ MSSA12 } & S1 & $\mathrm{S}$ & $\mathrm{S}$ & $\mathrm{S}$ & $\mathrm{S}$ & $\mathrm{S}$ & $\mathrm{S}$ \\
\hline & S2 & $S$ & I & S & I & $S$ & S \\
\hline & S3 & $S$ & $S$ & $S$ & $S$ & $S$ & $S$ \\
\hline \multirow[t]{3}{*}{ MSSA14 } & S1 & $\bar{S}$ & $\bar{S}$ & $\bar{S}$ & $\bar{S}$ & $\bar{S}$ & $\bar{S}$ \\
\hline & S2 & S & $S$ & $S$ & S & $S$ & $S$ \\
\hline & S3 & $\mathrm{R}$ & $\mathrm{S}$ & $\mathrm{R}$ & $\mathrm{S}$ & $S$ & $\mathrm{~S}$ \\
\hline \multirow[t]{3}{*}{ MSSA29 } & S1 & $\bar{S}$ & $\bar{S}$ & $\bar{S}$ & $\overline{\mathrm{R}}$ & $\bar{S}$ & $\bar{S}$ \\
\hline & S2 & S & S & $S$ & I & $S$ & S \\
\hline & S3 & $S$ & S & $S$ & $\mathrm{R}$ & $S$ & $S$ \\
\hline \multirow[t]{3}{*}{ S. aureusATCC25923 } & S1 & $\mathrm{S}$ & $\bar{S}$ & $\bar{S}$ & $\bar{S}$ & $\bar{S}$ & $\bar{S}$ \\
\hline & S2 & S & S & $S$ & S & S & S \\
\hline & S3 & $\mathrm{R}$ & S & $\mathrm{S}$ & $\mathrm{S}$ & S & $\mathrm{S}$ \\
\hline
\end{tabular}

$\mathrm{CFO}=$ Cefoxitin. $\mathrm{CLI}=$ Clindamycin. $\mathrm{OXA}=$ Oxacillin. $\mathrm{ERI}=$ Erythromycin. $\mathrm{CIP}=$ Ciprofloxacin. GEN $=$ Gentamicin .

Source: Authors.

Table 5. Susceptibility to antibiotics in methicillin-resistantStaphylococcus aureus(MRSA) wild type strains (S1), nisin-resistant strains (S2) and nisin-resistant strains consecutively transferred in BHI broth without nisin (S3).

\begin{tabular}{|c|c|c|c|c|c|c|c|}
\hline Antibiotic & & $\mathrm{CFO}$ & CLI & OXA & ERI & CIP & GEN \\
\hline \multirow{3}{*}{ MRSA03 } & $\begin{array}{l}\text { S1 } \\
\text { f }\end{array}$ & $\bar{R}$ & $\bar{S}$ & $\bar{R}$ & $\bar{S}$ & $\mathrm{~S}$ & $\bar{S}$ \\
\hline & S2 & $\mathrm{R}$ & S & S & I & $S$ & S \\
\hline & S3 & S & S & S & $\mathrm{R}$ & S & S \\
\hline \multirow[t]{3}{*}{ MRSA04 } & S1 & $\mathrm{R}$ & $\mathrm{S}$ & $\mathrm{R}$ & $\mathrm{S}$ & S & $\mathrm{S}$ \\
\hline & S2 & S & S & S & S & S & S \\
\hline & S3 & $\mathrm{R}$ & S & $\mathrm{R}$ & $\mathrm{R}$ & $S$ & $S$ \\
\hline \multirow[t]{3}{*}{ MRSA05 } & S1 & $\overline{\mathrm{R}}$ & $\bar{S}$ & $\overline{\mathrm{R}}$ & $\bar{S}$ & $\bar{S}$ & $\bar{S}$ \\
\hline & S2 & $\mathrm{R}$ & S & S & S & $S$ & S \\
\hline & S3 & $\mathrm{R}$ & S & $\mathrm{R}$ & $\mathrm{R}$ & $\mathrm{S}$ & $\mathrm{S}$ \\
\hline \multirow{3}{*}{ MRSA06 } & S1 & $\bar{R}$ & $S$ & $\bar{R}$ & I & $S$ & I \\
\hline & S2 & $\mathrm{R}$ & S & S & I & $S$ & S \\
\hline & S3 & $\mathrm{R}$ & S & $\mathrm{R}$ & I & S & S \\
\hline \multirow{3}{*}{ MRSA07 } & S1 & $\overline{\mathrm{R}}$ & $\mathrm{S}$ & $\overline{\mathrm{R}}$ & $\bar{S}$ & $\mathrm{~S}$ & $\bar{S}$ \\
\hline & $\mathrm{S} 2$ & $\mathrm{R}$ & S & $S$ & S & S & $S$ \\
\hline & S3 & $\mathrm{R}$ & S & $\mathrm{R}$ & $\mathrm{R}$ & S & S \\
\hline \multirow[t]{3}{*}{ S. aureusATCC33591 } & S1 & $\overline{\mathrm{R}}$ & $\overline{\mathrm{R}}$ & $\overline{\mathrm{R}}$ & $\overline{\mathrm{R}}$ & $\mathrm{S}$ & $\bar{S}$ \\
\hline & S2 & $\mathrm{R}$ & S & S & I & I & S \\
\hline & S3 & $\mathrm{R}$ & $\mathrm{S}$ & $\mathrm{R}$ & $\mathrm{R}$ & $\mathrm{S}$ & $\mathrm{S}$ \\
\hline
\end{tabular}

$\overline{\mathrm{CFO}}=$ Cefoxitin. $\mathrm{CLI}=$ Clindamycin. OXA $=$ Oxacillin. ERI $=$ Erythromycin. $\mathrm{CIP}=$ Ciprofloxacin. $\mathrm{GEN}=$ Gentamicin. 


\section{Discussion}

MRSA strains used in this study tested positive for the methicillin resistance gene mecA and negative for mecC, similar to that reported by Ceballos et al. (2019). Initially, mecC gene was only related to MRSA from animal origin, but it was rapidly detected in strains of human origin, making this pathogen an important zoonotic agent (Lozano et al., 2020). Lozano et al. (2020) also reported that although the prevalence of mecC-MRSA human infections is very low, "mecC-carrying MRSA should be taken into consideration in hospital, veterinary and food safety laboratories and in prevention strategies in order to avoid possible emerging health problems". Our results also showed that the MRSA strains produce the Panton Valentine Leukocidin (PVL), which characterizes them as CA-MRSA (Dufour et al., 2002; Kateete et al., 2019). Studies have shown that CA-MRSA has become the most significant pathogen in several parts of the world and its prevalence has surpassed HAMRSA cases. More worrying is the fact that CA-MRSA is becoming increasingly common in health facilities (Calfee, 2012; Togneri et al., 2017; Vuong et al., 2016; Kateete et al., 2019). This raises concern as they are more virulent than HA-MRSA and may further aggravate patient's health, thus development of alternative methods to control this pathogen are necessary.

Bacteriocins could be excellent candidates to control MRSA, as shown by several authors (Piper et al., 2009; Yang et al., 2014; Du et al., 2020). These antimicrobial peptides have no approval for human clinical use yet, although studies have shown their clinical potential as anti-cancer, anti-cariogenic, and to treat skin infections (Heunis et al., 2013; Ceotto-Vigoder et al. 2016; Hosseini et al., 2020). More recently, nisin has been pointed as a potential treatment strategy for COVID-19, due to the affinity to the same receptor used by Coronavirus to infect cells (Bhattacharya et al., 2021). Bacteriocins have also shown the potential to control antibiotic-resistant pathogens (Jensen et al., 2020; Okuda et al., 2013; 1., 2014). In addition, bacteriocins generally show high stability, low toxicity, and broad and narrow spectrum of activity (Cotter, et al., 2013).

The results presented in this study show that nisin is effective in controlling MSSA and MRSA. We tested both the MRSA and MSSA to find out whether these strains show the same response to nisin with respect to its antimicrobial activity. Nisin was found to be bactericidal against most of the tested strains and sensitivity to this bacteriocin was a heterogeneous characteristic among MRSA and MSSA, considering their MIC and MBC values. Moreover, our results showed that, generally, MRSA required higher doses of bacteriocin for inhibition or cell death, as more than 50\% of MSSA tested showed MIC values lower than the minimum value observed for MRSA. Dosler \& Gerceker (2012) also compared the activity of nisin against MRSA and MSSA, but they found no difference in sensitivity to nisin. Our findings reinforce the varied sensitivity to bacteriocin among S. aureus strains and emphasizes the need for detailed investigation prior to its therapeutic application.

Although many studies have shown the effectiveness of nisin in controlling MRSA, in most cases the easiness with which nisin-resistant strains can be selected is not verified. Only MSSA have been tested for the selection of resistance against nisin. As stated by Blake et al. (2011), detailed resistance studies with relevant bacterial pathogens are lacking and little is known about the impact that their use may have on the selection of bacteriocin resistant strains. In this study, after exposure to the sublethal doses of nisin, both the MRSA and MSSA showed nisin resistance by increase in their MIC value of up to 250 times. Nisin resistance was maintained even when the strains were grown in the absence of nisin, indicating that a genetic modification could be associated with nisin resistance. MRSA, which was less sensitive to nisin, required less contact with the bacteriocin to eliminate completely the bacteriocin activity. This result indicated that MRSA could be more susceptible to nisin-resistance than MSSA. Further studies will be carried out to analyze the nisin-resistance mechanisms in these strains.

Initially, bacteriocin resistance was mostly associated with easily reversible physiological adaptation (Mantovani \& Russell, 2001; Masias et al., 2017). However, studies indicate genetic modification as a determinant to bacteriocin resistance. Blake et al. (2011) associated nisin resistance in S. aureus with modification in a sensor histidine kinase of a two-component system. Hiron et al. (2011) also related nisin resistance with a two-component system and with an ABC-transporter used as a 
detoxification module. These results also suggest that several mechanisms may confer resistance to nisin.

Some authors emphasize that resistance to bacteriocins may alter the antibiotic susceptibility of bacterial strains, and bacteriocin resistance may confer cross-resistance to antibiotics (Kaur et al. 2014; Martínez \& Rodríguez, 2005). However, specifically for S. aureus, Blake et al. (2011) found that resistance to nisin did not alter the antibiotic susceptibility of this microorganism. Our results showed that nisin resistance affected antibiotic susceptibility of both MRSA and MSSA, mainly to Cefoxitin, Oxacillin, and Erythromycin. Most of the strains that had sensitivity to CFO modified also had sensitivity to OXA altered, which is explained by the fact that they share a similar mechanism of action.

Three MSSA strains became oxacillin-resistant and one MRSA strain became oxacillin-sensitive after exposure to the sublethal doses of nisin. As the mecA gene, which confers resistance to methicillin and, consequently, to oxacillin, was not detected in the MSSA strains (results not shown), another methicillin resistance mechanism may be involved, or nisinresistance mechanisms could confer cross-resistance to oxacillin. On the other hand, the mecA gene was still detected in MRSA that became oxacillin-sensitive upon exposure to nisin, indicating that gene expression could probably be affected. Alves et al., (2020) showed that MRSA strains treated with nisin and/or oxacillin showed altered protein expression compared to the control treatment, including resistance and extress response genes. Lee et al. (2013) also tested the inhibitory activity of bacteriocin KU24 against MRSA and verified that the bacteriocin impaired the mecA expression. However, our results showed that even in the absence of nisin, the oxacillin-susceptible phenotype was maintained, indicating a permanent modification and probable involvement of another mechanism. These results indicated that nisin resistance is a complex trait that have to be further analyzed for a successful clinical application of this bacteriocin.

Although resistance to nisin is a trait possible to find in MRSA, bacteriocins have some advantages over antibiotics. To date, bacteriocin resistance has been reported only in vitro. Therefore, considering that bacteriocins have not yet been used on the same scale as antibiotics, a bacteriocin-resistant population does not exist (Draper et al., 2015). Besides, nisin have a dual mechanism of action not shared by other therapeutic compounds in use, which reduces the probability of selecting resistant strains (Van Heel et al., 2013). Unlike most antibiotics, which are secondary metabolites, bacteriocins are ribossomally synthesized, which allows bioengineering to improve its efficiency (Yang et al., 2014), a tool that can be used to overcome resistance mechanisms.

\section{Final Considerations}

Considering the nisin resistance phenotype observed in this study and reported in other studies as well, it can be concluded that the clinical application of nisin will depend on the understanding of the resistance mechanisms and the development of strategies to prevent the emergence of resistance in future. The best way to use nisin therapeutically maybe in combination with traditional antibiotics. In addition, many other challenges such as a more effective way to administer bacteriocin therapeutically need to be addressed.

\section{Acknowledgments}

The authors would like to thank Conselho de Desenvolvimento Científico e Tecnológico (CNPq) and Coordenação de Aperfeiçoamento de Pessoal de Nível Superior (CAPES).

\section{References}

Alves, F. C. B., Albano, M., Andrade, B. F. M. T., Chechi, J. L., Pereira, A. F. M., Furlanetto, A., ... Fernandes, A. (2020). Comparative Proteomics of Methicillin-Resistant Staphylococcus aureus Subjected to Synergistic Effects of the Lantibiotic Nisin and Oxacillin. Microbial Drug Resistance, 26(3), 179189. 
Bauer, P. R., \& Sampathkumar, P. (2017). Methicillin-resistant Staphylococcus aureus infection in ICU: What is the best prevention strategy? Critical Care Medicine, 45 (8), 1413-1414.

Bhattacharya, R., Gupta, A.M., Mitra, S., Mandal, S., Biswas, S.R. (2021). A natural food preservative peptide nisin can interact with the SARS-CoV-2 spike protein receptor human ACE2. Virology, 2 (552), 107-111.

Blake, K. L., Randall, C. P., \& O’Neill, A. J. (2011). In vitro studies indicate a high resistance potential for the lantibiotic nisin in Staphylococcus aureus and define a genetic basis for nisin resistance. Antimicrobial Agents and Chemotherapy, 55(5), 2362-2368.

Cafiso, V., Stracquadanio, S., Lo Verde, F., De Guidi, I., Zega, A., Pigola, G., \& Stefani, S. (2020). Genomic and Long-Term Transcriptomic Imprints Related to the Daptomycin Mechanism of Action Occurring in Daptomycin- and Methicillin-Resistant Staphylococcus aureus Under Daptomycin Exposure. Frontiers in Microbiology, 11, 1893.

Calfee, D. P. (2012, August). Methicillin-resistant Staphylococcus aureus and vancomycin-resistant enterococci, and other Gram-positives in healthcare. Current Opinion in Infectious Diseases, 25 (4), 385-394.

Castro, A., Palhau, C., Cunha, S., Camarinha, S., Silva, J., \& Teixeira, P. (2017). Virulence and resistance profile of Staphylococcus aureus isolated from food. Acta Alimentaria, 46(2), 231-237.

Ceballos, S., Aspiroz, C., Ruiz-Ripa, L., Azcona-Gutierrez, J.M., López-Cerero, L., López-Calleja, A.I., Álvarez, L., Gomáriz, M., Fernández, M., Torres, C. (2019). Multicenter study of clinical non-beta-lactam-antibiotic susceptible MRSA strains: Genetic lineages and Panton-Valentine leukocidin (PVL) production. Enfermedades Infecciosas y Microbiología Clínica, 37(8):509-513.

Center for Disease Control and Prevention. (2015). Morbidity And Mortality Weekly Report. Retrieved September 6, 2019, from https://www.cdc.gov/mmwr/index2015.html

Ceotto-Vigoder, H., Marques, S. L. S., Santos, I. N. S., Alves, M. D. B., Barrias, E. S., Potter, A., ... Bastos, M. C. F. (2016). Nisin and lysostaphin activity against preformed biofilm of Staphylococcus aureus involved in bovine mastitis. Journal of Applied Microbiology, 121(1), 101-114.

Cleveland, J., Montville, T. J., Nes, I. F., \& Chikindas, M. L. (2001). Bacteriocins: Safe, natural antimicrobials for food preservation. International Journal of Food Microbiology, Vol. 71 (1), 1-20.

Clinical and Laboratory Standarts Institute. n.d. (2019). "Performance Standards for Antimicrobial Susceptibility Testing. 27th Ed. CLSI Supplement M100 .

Cotter, P. D., Ross, R. P., \& Hill, C. (2013). Bacteriocins-a viable alternative to antibiotics? Nature Reviews Microbiology, 11 (2), $95-105$.

Dosler, S., \& Gerceker, A. A. (2012). In vitro activities of nisin alone or in combination with vancomycin and ciprofloxacin against methicillin-resistant and methicillin-susceptible Staphylococcus aureus strains. Chemotherapy, 57(6), 511-516.

Draper, L. A., Cotter, P. D., Hill, C., \& Ross, R. P. (2015). Lantibiotic Resistance. Microbiology and Molecular Biology Reviews, 79(2), 171-191.

Du, H., Zhou, L., Lu, Z., Bie, X., Zhao, H., Niu, Y. D., \& Lu, F. (2020). Transcriptomic and proteomic profiling response of methicillin-resistant Staphylococcus aureus (MRSA) to a novel bacteriocin, plantaricin GZ1-27 and its inhibition of biofilm formation. Applied Microbiology and Biotechnology, 104(18), 7957-7970.

Dufour, P., Gillet, Y., le Bes, M., Lina, G., ois Vandenesch, F., Floret, D., ... Richet, H. (2002). Community-Acquired Methicillin-Resistant Staphylococcus aureus Infections in France: Emergence of a Single Clone That Produces Panton-Valentine Leukocidin. Clinical Infectious Disease, 35(7):819-24.

Field, D., Cotter, P. D., Hill, C., \& Ross, R. P. (2015). Bioengineering lantibiotics for therapeutic success. Frontiers in Microbiology, 27 (6), 1363.

Gedarawatte, S. T. G., Ravensdale, J. T., Al-Salami, H., Dykes, G. A., \& Coorey, R. (2021). Antimicrobial efficacy of nisin-loaded bacterial cellulose nanocrystals against selected meat spoilage lactic acid bacteria. Carbohydrate Polymers, 251, 117096.

Hanchi, H., Hammami, R., Gingras, H., Kourda, R., Bergeron, M. G., Ben Hamida, J., ... Fliss, I. (2017). Inhibition of MRSA and of Clostridium difficile by durancin 61A: Synergy with bacteriocins and antibiotics. Future Microbiology, 12(3), 205-212.

Hayes, K., Cotter, L., \& O’Halloran, F. (2019). In vitro synergistic activity of erythromycin and nisin against clinical Group B Streptococcus isolates. Journal of Applied Microbiology, 127(5), 1381-1390.

Heunis, T. D. J., Smith, C., \& Dicks, L. M. T. (2013). Evaluation of a nisin-eluting nanofiber scaffold to treat Staphylococcus aureus-induced skin infections in mice. Antimicrobial Agents and Chemotherapy, 57(8), 3928-3935.

Hiramatsu, K., Suzuki, E., Takayama, H., Katayama, Y., \& Yokota, T. (1990). Role of penicillinase plasmids in the stability of the mecA gene in methicillinresistant Staphylococcus aureus. Antimicrobial Agents and Chemotherapy, 34(4), 600-604.

Hiron, A., Falord, M., Valle, J., Débarbouillé, M., \& Msadek, T. (2011). Bacitracin and nisin resistance in Staphylococcus aureus: A novel pathway involving the BraS/BraR two-component system (SA2417/SA2418) and both the BraD/BraE and VraD/VraE ABC transporters. Molecular Microbiology, 81(3), 602622.

Hosseini, S. S., Goudarzi, H., Ghalavand, Z., Hajikhani, B., Rafeieiatani, Z., \& Hakemi-Vala, M. (2020). Anti-proliferative effects of cell wall, cytoplasmic extract of Lactococcus lactis and nisin through down-regulation of cyclin d1 on sw480 colorectal cancer cell line. Iranian Journal of Microbiology, 12(5), 424-430.

Jensen, C., Li, H., Vestergaard, M., Dalsgaard, A., Frees, D., \& Leisner, J. J. (2020). Nisin Damages the Septal Membrane and Triggers DNA Condensation in Methicillin-Resistant Staphylococcus aureus. Frontiers in Microbiology, 11 (1007), 1-8. 
Kang, J., Wiedmann, M., Boor, K. J., \& Bergholz, T. M. (2015). VirR-mediated resistance of Listeria monocytogenes against food antimicrobials and crossprotection induced by exposure to organic acid salts. Applied and Environmental Microbiology, 81(13), 4553-4562.

Kateete, D. P., Bwanga, F., Seni, J., Mayanja, R., Kigozi, E., Mujuni, B., ... Joloba, M. L. (2019). CA-MRSA and HA-MRSA coexist in community and hospital settings in Uganda. Antimicrobial Resistance and Infection Control, 8(1), 1-9.

Kaur, G., Singh, T. P., Malik, R. K., Bhardwaj, A., \& De, S. (2014). Antibacterial efficacy of nisin, pediocin 34 and enterocin FH99 against L. monocytogenes, E. faecium and E. faecalis and bacteriocin cross resistance and antibiotic susceptibility of their bacteriocin resistant variants. Journal of Food Science and Technology, 51(2), 233-244.

Kranjec, C., Ovchinnikov, K. V., Grønseth, T., Ebineshan, K., Srikantam, A., \& Diep, D. B. (2020). A bacteriocin-based antimicrobial formulation to effectively disrupt the cell viability of methicillin-resistant Staphylococcus aureus (MRSA) biofilms. Npj Biofilms and Microbiomes, 6(1), 1-13.

Lakhundi, S., \& Zhang, K. (2018). Methicillin-Resistant Staphylococcus aureus: Molecular Characterization, Evolution, and Epidemiology. Clinical Microbiology Reviews, 31(4), 1-103.

Lee, N. K., Jin Han, E., Jun Han, K., \& Paik, H. D. (2013). Antimicrobial effect of bacteriocin KU24 produced by lactococcus lactis KU24 against methicillinResistant Staphylococcus aureus. Journal of Food Science, 78(3), 465-469.

Lozano, C., Fernández-Fernández, R., Ruiz-Ripa, L., Gómez, P., Zarazaga, M., \& Torres, C. (2020). Human mecC-carrying MRSA: Clinical implications and risk factors. Microorganisms, 8(10), 1-20.

Mantovani, H. C., \& Russell, J. B. (2001). Nisin Resistance of Streptococcus bovis. APPLIED AND ENVIRONMENTAL MICROBIOLOGY, 67(2), 808-813.

Martínez, B., \& Rodríguez, A. (2005). Antimicrobial susceptibility of nisin resistant Listeria monocytogenes of dairy origin. FEMS Microbiology Letters, 252(1), 67-72.

Masias, E., Dupuy, F. G., da Silva Sanches, P. R., Farizano, J. V., Cilli, E., Bellomio, A., ... Minahk, C. (2017). Impairment of the class IIa bacteriocin receptor function and membrane structural changes are associated to enterocin CRL35 high resistance in Listeria monocytogenes. Biochimica et Biophysica Acta - General Subjects, 1861(7), 1770-1776.

Okuda, K. I., Zendo, T., Sugimoto, S., Iwase, T., Tajima, A., Yamada, S., ... Mizunoe, Y. (2013). Effects of bacteriocins on methicillin-resistant Staphylococcus aureus biofilm. Antimicrobial Agents and Chemotherapy, 57(11), 5572-5579.

Pader, V., \& Edwards, A. M. (2017). Daptomycin: New insights into an antibiotic of last resort. Future Microbiology, 12, 461-464.

Piper, C., Draper, L. A., Cotter, P. D., Ross, R. P., \& Hill, C. (2009). A comparison of the activities of lacticin 3147 and nisin against drug-resistant Staphylococcus aureus and Enterococcus species. Journal of Antimicrobial Chemotherapy, 64(3), 546-551.

Punjabi, C., Madaline, T., Gendlina, I., Chen, V., Nori, P., \& Pirofski, L. A. (2020). Prevalence of methicillin-resistant

Staphylococcus aureus (MRSA) in respiratory cultures and diagnostic performance of the MRSA nasal polymerase chain reaction (PCR) in patients hospitalized with coronavirus disease 2019 (COVID-19) pneumonia. Infection Control \& Hospital Epidemiology, https://doi.org/10.1017/ice.2020.4402.

Saha, S., Das, A., Debnath, A., Begam, S., Sen, S., Majumdar, S., \& Sil, S. K. (2017). Increased ROS Generation: Implication in Antibacterial Activity of Evolvulus nummularius against Multidrug Resistant Gram Negative Bacterial Strains. International Journal of Current Microbiology and Applied Sciences 6(1), 100-107.

Sharifipour, E., Shams, S., Esmkhani, M., Khodadadi, J., Fotouhi-Ardakani, R., Koohpaei, A., ... Ej Golzari, S. (2020). Evaluation of bacterial co-infections of the respiratory tract in COVID-19 patients admitted to ICU. BMC Infectious Diseases, 20(1), 1-7.

Shin, J. M., Gwak, J. W., Kamarajan, P., Fenno, J. C., Rickard, A. H., \& Kapila, Y. L. (2016). Biomedical applications of nisin. Journal of Applied Microbiology, 120, 1449-1465.

Shokri, D., Zaghian, S., Khodabakhsh, F., Fazeli, H., Mobasherizadeh, S., \& Ataei, B. (2014). Antimicrobial activity of a UV-stable bacteriocin-like inhibitory substance (BLIS) produced by Enterococcus faecium strain DSH20 against vancomycin-resistant Enterococcus (VRE) strains. Journal of Microbiology, Immunology, and Infection, 47(5), 371-376.

Smith, M. K., Draper, L. A., Hazelhoff, P. J., Cotter, P. D., Ross, R. P., \& Hill, C. (2016). A bioengineered nisin derivative, M21A, in combination with food grade additives eradicates biofilms of Listeria monocytogenes. Frontiers in Microbiology, 7(1939), 1-11.

Togneri, A. M., Podestá, L. B., Pérez, M. P., \& Santiso, G. M. (2017). Study of Staphylococcus aureus infections in a general acute care hospital (2002-2013). Revista Argentina de Microbiologia, 49(1), 24-31.

Vivas, R., Barbosa, A. A. T., Dolabela, S. S., \& Jain, S. (2019). Multidrug-Resistant Bacteria and Alternative Methods to Control Them: An Overview. Microbial Drug Resistance, 25(6), 890-908.

Vuong, C., Yeh, A. J., Cheung, G. Y. C., \& Otto, M. (2016, January 2). Investigational drugs to treat methicillin-resistant Staphylococcus aureus. Expert Opinion on Investigational Drugs, Vol. 25, pp. 73-93.

Yang, S. C., Lin, C. H., Sung, C. T., \& Fang, J. Y. (2014). Antibacterial activities of bacteriocins: Application in foods and pharmaceuticals. Frontiers in Microbiology, 5, 241. 